\title{
Production and Quality Evaluation of Instant Sorrel (Zobo) Drink Produced by Infusion, Dehydration and Size Reduction Methods
}

\author{
Mohammed $\mathrm{SF}^{1}$, Gimba $\mathrm{IK}^{1}$ and Bahago $\mathrm{EJ}^{2}$ \\ ${ }^{1}$ Department of Food Science \& Technology, Federal Polytechnic, PMB 1012, Kaura Namoda, Zamfara State, Nigeria \\ ${ }^{2}$ National Agency for Science and Engineering Infrastructure, Idu Industrial Area, Garki, Abuja, Nigeria \\ *Corresponding author: Mohammed SF, Department of Food Science \& Technology, Federal Polytechnic, \\ PMB 1012, KauraNamoda, Zamfara State, Nigeria, Tel: +234 7011626925, E-mail: smfuntua@gmail.com
}

Citation: Mohammed SF, Gimba IK, Bahago EJ (2017) Production and Quality Evaluation of Instant Sorrel (Zobo) Drink Produced by Infusion, Dehydration and Size Reduction Methods. J Nutr Health Sci 4(2): 205. doi: 10.15744/2393-9060.4.205

Received Date: April 21, 2017 Accepted Date: July 13, 2017 Published Date: July 17, 2017

\begin{abstract}
Instant sorrel drink (IZD) was developed by processing purple sorrel calyx into powdery form by the method of infusion, and dehydration and size reduction. Another purple sorrel calyx was processed into liquid zobo drink (LZD); and both the IZD and LZD were subjected to sensory evaluation using the total number of thirty five (35) panels of judges and data was subjected to t-test and preference test analytical tools; and found that IZD was also acceptable by the sensory panelists because the T-tabulated is 2.064 , while T-calculated is -14.37 with standard deviations of $0.32(\mathrm{P} \geq 0.05)$ between the means; hence, there was no significance difference between the reconstituted IZD and the LZD, because T-calculated is not greater than the T-tabulated. Only IZD was further subjected to proximate, crude fibre, nutritional and microbiological analyses. IZD is rich in carbohydrates; and it contained appreciable quantity of protein, fat, ash, crude fibre, fructose, glucose, iron, carotene, vitamin C and calorific value, respectively. Also, IZD was found to be safe microbiologically for human consumption. The moisture content of IZD was extremely low indicating the possibility of the drink to have longer shelf life.
\end{abstract}

Keywords: Sorrel calyx; Granulated sugar; Infusion; Dehydration and Size Reduction Method; Unsweetened Sorrel powder; Instant sorrel drink; Quality evaluations

\section{Introduction}

Due to the popularity, continuous and increasing demand for shelf stable zobo drink to support the growing demand of zobo drink consumers in Nigeria, research efforts need to be redirected towards new technology for zobo drink (ZD) production from sorrel calyx. ZD is usually prepared at home by housewives or those on low income as a way of earning additional money to support immediate and extended family members; and it is usually sold in motor-parks, on school premises, and in restaurants and markets especially during the summer when the temperature goes above $37^{\circ} \mathrm{C}$ [1]. It is also served during naming and marriage ceremonies and over festival periods [2]. It is usually drunk in the afternoon especially during the summer and the winter; it is rarely drunk in the spring. Most people consume moderately chilled ZD and only a few people prefer chilled or warm $\mathrm{ZD}$, and it is drunk by all sectors of the Nigerian population above the age of 10 [1]. ZD is usually prepared from the calyx of Sorrel. Nutritionists have found Roselle calyces hawked in Central American markets to contain high amounts of calcium, niacin, riboflavin and iron [2]. Also, another study reported the medicinal potentialities of Sorrel calyces by managing patients suffering from Type II Diabetes because of the hypoglycemic and hypolipidemic effects of the calyces of Sorrel; hence, calyces of Sorrel can improve the lipid profiles of the diabetics [3].

Sorrel calyx is indigenous to the tropics and it is used to produce liquid zobo drink (LZD) in Nigeria. Zobo, English speaking people describes it as sorrel; the French refers to it as Orselle; and the Arab speaking nations name it Karkade. In Nigeria different people from different ethnic group call it various names; and the three major ethnic groups (i.e. Yoruba, Hausa and Igbo) in Nigeria call it Isapa, zobo and Aukan, respectively [4]. Also, Muhammad \& Umar (2007) reported that Sorrel is given to any shrub of a large genus of low succulent plant or any of the various plants having in their leaves acid sap that gives a sour flavour; and the acidity may result from the presence of one or more acids; the commonest being citric, malic and oxalic acids, respectively [2]. The two botanical varieties of sorrel plant according to Morton (1999) are Hibiscus sabdariffa variety altissima and Hibiscus sabdariffa variety sabdarriffa [5]. Also, Muhammad \& Umar (2007) highlighted that three botanical varieties are recognized in Nigeria and 
they are available in the northern parts, these include: the red, purple and cream calyces and it is recently observed that the purple are of two types; extremely dark purple and lightly dark purple; the red and purple verities are used for the production of Zobo drinks while the cream calyx in combination with the sorrel leaf is used in the preparation of soup popularly known as 'Miyan Taushe' in the northern part of Nigeria [2,6]. Morton (1999) reports that sorrel calyx is a rich source of calcium, riboflavin, niacin, and iron; the same report states that the fresh calyces contains per $100 \%$ edible portion; $9.2 \%$ moisture, $1.145 \%$ protein, $2.61 \%$ fat, $12.0 \%$ fibre, $6.90 \%$ ash; with considerable amount of minerals, vitamins and appreciable amount of amino acids. A study reveals that Leaf and calyx of sorrel plant are rich in vitamin C (Ascorbic Acid), Riboflavin and some of the major minerals [5,7]. Another study exposes that the major sugar in Roselle calyces has been found to be glucose, sucrose and fructose, and the sorrel calyces are thus characterized as a highly acidic fruit with low sugar content $[6,8]$. Another finding discloses that Roselle is rich in anthocyanins; and the calyces of Roselle are ideal for producing brilliant red colouring in galatin, jellies and fruit beverages [9,10]. A study makes known that DP 3-sambubioside is the major pigment responsible for the reddish-violet colour of red and purple sorrel calyces used in the production of zobo drink. In fact, the Red specie of Sorrel has been approved as a colouring agent for the production of beverages by the United States Food and Drugs Administration[10,11].

Zobo drink is a traditional beverage usually produced into liquid form by either boiling or steeping the calyx of sorrel in potable water and sweetened by sugar, and then refrigerated before serving chilled to consumers [4]. The red and/or purple succulent calyces are boiled, sieved, sweetened with sugar, and flavoured with pineapple juice, ginger and lemon to produce sorrel drink [12]. The calyx can also be boiled with pineapple peels during the extraction process to enhance the taste of the extracted Zobo liquor before sweetened with sugar or other sweetening agents such as Honey. A study reports that the dry red calyces are commonly used as tea, consumed hot or cold after sweetening with nutritive sweeteners such as sucrose, which have a tart flavour, and they are as well used as food colouring agent [2]. But, Sorrel drink in liquid form (LZD) goes sour and becomes fermented within twenty four (24) hours after production, which subsequently lead to the spoilage of the drink as observed by [13]. However, study conducted by Alobo et al. established that about $8 \%$ perceived that liquid sorrel drink is produced un-hygienically at homes by cottage producers [1]. It is not surprising that are of the opinion that instability of liquid zobo drink (LZD) stored at ambient (37 ${ }^{\circ} \mathrm{C}$ ) or refrigeration $\left(4-5^{\circ} \mathrm{C}\right)$ temperatures shortly and/or few days after production is a major hindrance to its general acceptability by some consumers and large-scale production and marketability [14]. Like most drinks, yeasts, moulds and bacteria are the spoilage organisms in LZD if kept for more than three days or less, because these microbes initiate and support fermentation progressively giving rise to off-flavour and carbon-dioxide production resulting to spoilage of LZD, while some bacteria make LZD potentially health hazard to consumers if LZD is consumed having high population of bacterial cells and/or spores [4,14]. Hence Nwachukwu, Onovo and Eadie (2007) isolated Staphylococcus aureus, Escherichia coli, lactobacillus sp., pseudomonas aeroginosa, and Bacillus subtilis from LZD produced at home and sold in local markets [15]. This necessitates the application of new technology in the production of sorrel drink into powdery form so that a better quality, longer shelf-life and consumer appeal sorrel drink can be made available to consumers. This necessitates the need to produce sorrel drink in an instant form so that its shelf life could be prolonged without the addition of chemical preservatives. Therefore, the purpose of this study is to develop an instant sorrel drink (IZD) by infusion, dehydration and Pulverisation method and subjecting it to quality evaluation to establish its nutritional, sensory and microbiological qualities for human use and consumption.

\section{Materials and Methods}

\section{Raw Materials}

For the purpose of this study the purple sorrel calyx was used for the preparation of LZD and IZD being the commonest species used for the production of LZD; and also granulated sugar, PET container, 2-ply laminates package and labeled primary package were purchased at Kaura-Namoda central market, Kaura-Namoda Local Government Area, Zamfara state and Abubakar Gumi central market, Kaduna, Kaduna state, Nigeria. This study was conducted between May, 2010 to September, 2010 at the department of Food Science and Technology, Federal Polytechnic, KauraNamoda, Zamfara state, and College of Food Technology, department of Food Science and Technology, Federal University of Agriculture, Makurdi, Benue state, Nigeria.

\section{Development of Instant Sorrel Drink (IZD)}

IZD was produced by the method of infusion, dehydration and size reduction method. In this method, dark purple sorrel calyx was cleaned, sorted, de-stemmed and $500 \mathrm{~g}$ weighed into a stainless jar containing $250 \mathrm{ml}$ potable water. This was infused by heating in a close system steam chamber at $72{ }^{\circ} \mathrm{C} \pm 2{ }^{\circ} \mathrm{C}$ for 90 mins after which the infused calyx was dehydrated at $72{ }^{\circ} \mathrm{C} \pm 2{ }^{\circ} \mathrm{C}$ for $5 \mathrm{hrs}$ and $45 \mathrm{mins}$. The dehydrated sorrel calyx was cooled; pulverized, sieved using digital sieve of 0.5 micro sieve and fine instant unsweetened sorrel powder was produced. Then granulated sugar was heat-treated, cooled and pulverized into powdery form. Both products were then mixed together to produce a homogenous instant sweetened zobo drink (Figure 1) [2,17]. The mixture of the unsweetened pulverized sorrel powered and the sucrose were ratio nine to one (9:1) (Table 1).

\begin{tabular}{|c|c|}
\hline Ingredient & Quantity (g) \\
\hline Pulverized sorrel calyx powder & 100 \\
\hline Pulverized sugar & 900 \\
\hline
\end{tabular}

Table 1: Formulation of Ingredients for Production of IZD 


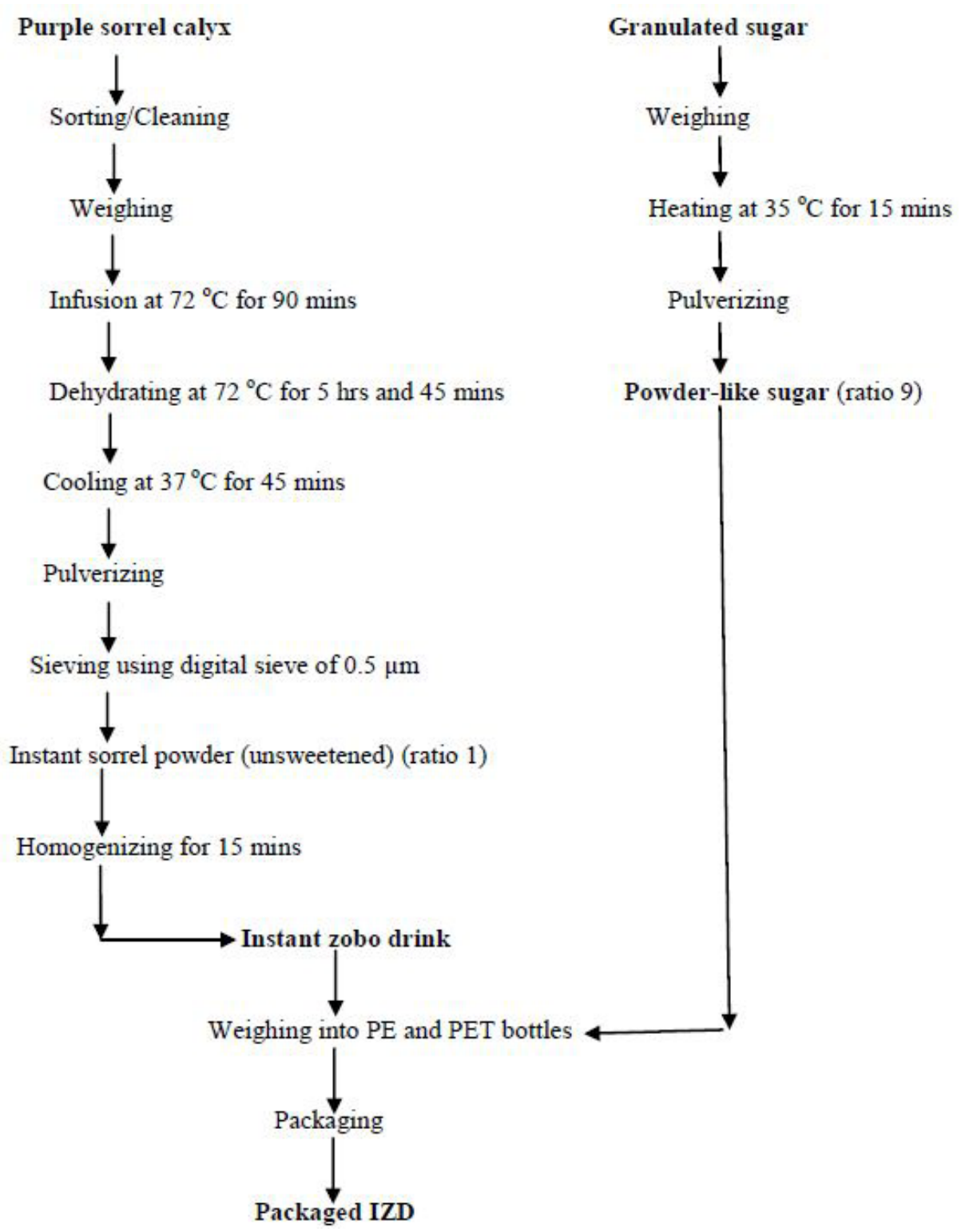

Figure 1: Process Flow Diagram for the Production of IZD Using Infusion/Dehydration Method

\section{Ingredients Formulation and Mixing Operation of IZD}

This was achieved by weighing 100g of unsweetened, pulverized sorrel calyx and $900 \mathrm{~g}$ (Table 1) of pulverized sugar into a stainless jar; and both ingredients were homogenized by a dry-mixer for about 5 mins to achieve a homogenous mixture, after which sweetened instant zobo drink (IZD) was produced (Figure 1). Table 1 demonstrates the formulation ratio for the production of IZD.

Figure 1 demonstrates the unit operations employed in the production of IZD using the method of infusion, dehydration and size reduction method; as well as the packaging materials used in the packaging operation of the developed IZD.

\section{Instant Zobo Drink (IZD)}

IZD was produced by the method of infusion, dehydration and size reduction method. Other product discovered was Zobo Tea (Figures 1-4).

\section{Packaging of Instant Zobo Drink (IZD)}

This was achieved by packaging IZD in a well labeled polyethylene terephthalate (PET) containers; polyethylene (PE) and printed paper package according to the description of $[2,17]$. The net content of PET container is $100 \mathrm{~g}$ (Figure 2), while that of printed package is $25 \mathrm{~g}$ (Figure 3), respectively. The packaged samples of IZD were stored away in a cool-dry environment for quality evaluations. 


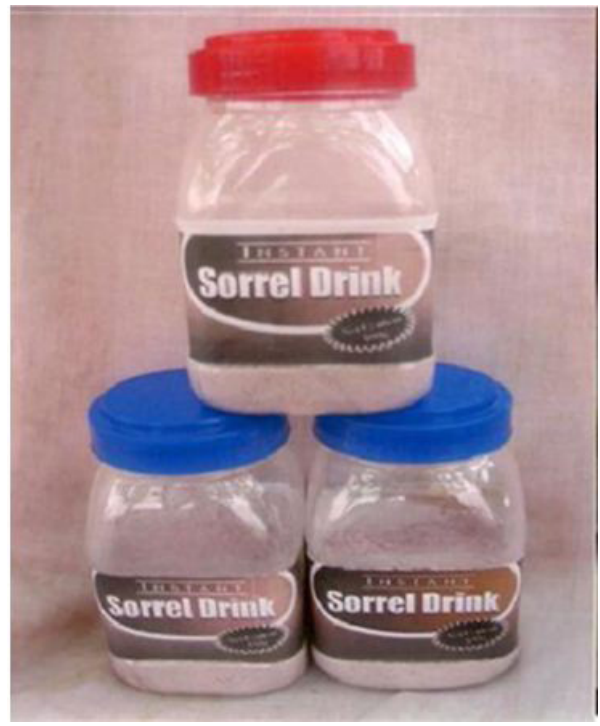

Figure 2: $100 \mathrm{~g}$ Net Weight IZD

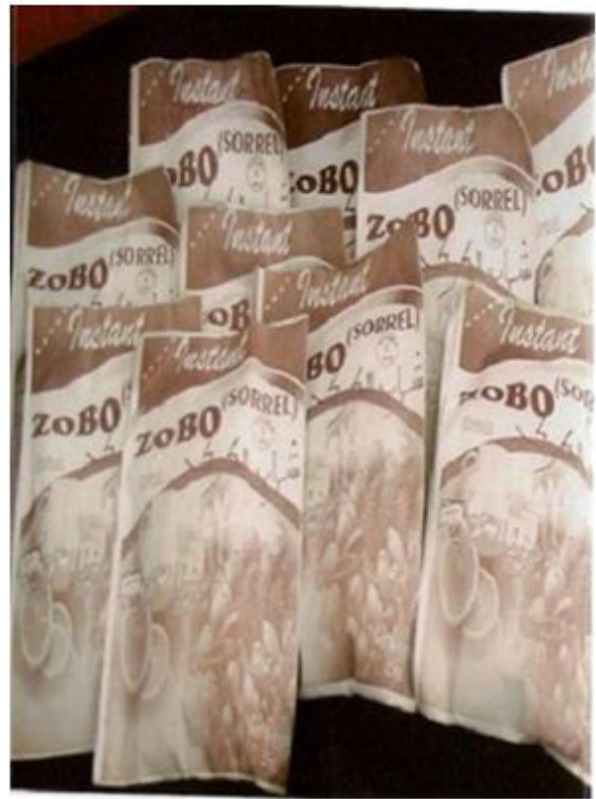

Figure 3: $25 \mathrm{~g}$ Net Weight IZD

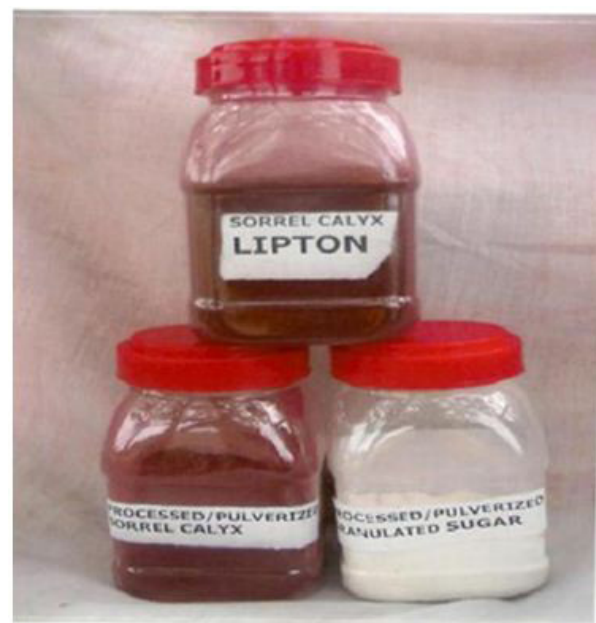

Figure 4: Zobo powder, Zobo tea and Pulverized sugar

\section{Reconstitution Ratio of the IZD}

$25 \mathrm{~g}$ of the IZD was mixed with a glass $(250 \mathrm{ml})$ of chilled water and served chilled. While $100 \mathrm{~g}$ of the drink in a PET container was mixed with five glasses $(1,250 \mathrm{ml})$ of cold water and serve chilled to the members of panelist (males and females). 


\section{Proximate Composition, Energy (Calorific) Value and Crude Fibre Conducted on IZD}

The moisture, ash and fat contents were determined using AOAC (2000), while protein was determined by Micro Kjeldahl Method of (Pearson, 1976) [18,19]. The carbohydrate was determined by difference as described by Onwuka (2005) [20]. While energy (calorific) value was calculated by multiplying the grams of protein, fat, and carbohydrate by the factors of 4,9 , and $4 \mathrm{kcal} / \mathrm{g}$ [21,24].

\section{Nutritional Composition of IZD}

Iron, Glucose, Fructose, Carotene and vitamin C contents were determined according to AOAC (2000), and Pearson (1976) $[18,19]$. A.A.S and U.V. Spectrophotometer were used in the analysis of iron and carotene content of the IZD.

\section{Microbiological Analysis of IZD}

Microbiological analysis such as yeasts, moulds, coliform and total aerobic counts were conducted on the IZD sample using method described by Health Protection Agency [23].

\section{Sensory Evaluation of IZD}

Sensory evaluation was conducted in the morning between the hour of 9 am to 12 noon on the developed instant zobo drink (IZD) after reconstitution to compare with liquid zobo drink (LZD) sold in local market with the reference codes 631 and 531, respectively. The coded samples were presented to a 10-people and 25-people panelist, respectively. The sensory panelists (males and females) between the ages of 18 to 35 known for consumption of LZD were employed for sensory analysis of both the LZD and the reconstituted IZD. The panelists were asked to compare both samples of the drinks based on colour, taste, flavour and overall acceptability. Both samples of IZD and LZD were subjected to sensory analysis using 9-points Hedonic scale for data generation; while t-Test and preference test were used as statistical tools to analyse data according to the methods described by Ihekoronye \& Ngoddy (1985) andIwe (2007), respectively [24,25].

\section{Results}

The IZD developed was analysed for proximate composition, energy value, nutritional and microbial quality, respectively. And the following results were obtained (Figure 5 and 6). Figure 5 presents the proximate composition of the IZD developed.

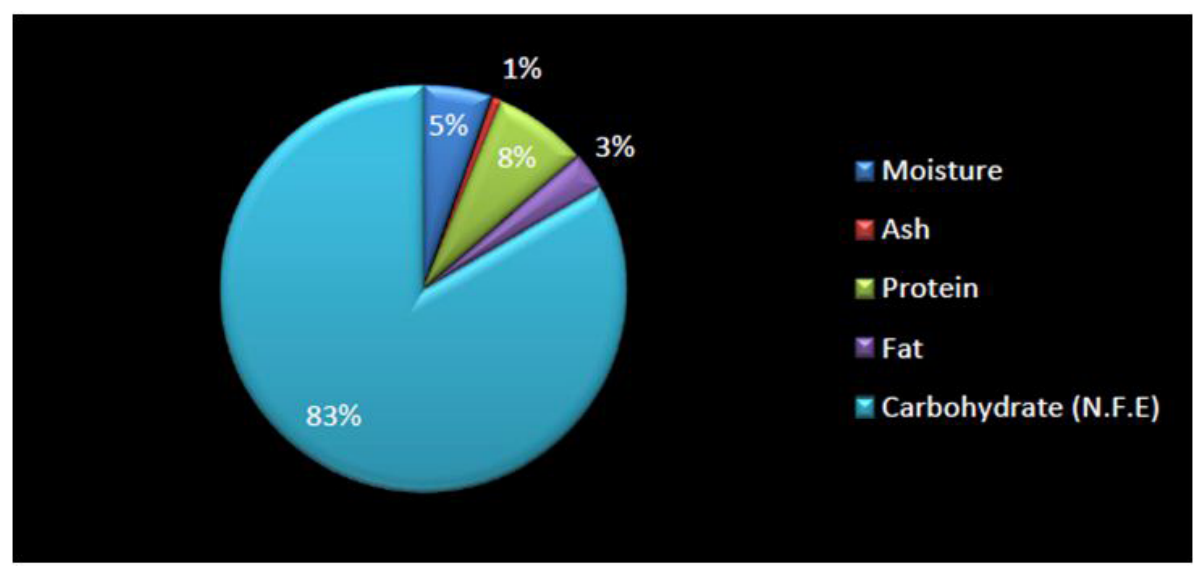

Figure 5: Graphical Representation for Proximate Composition of IZD

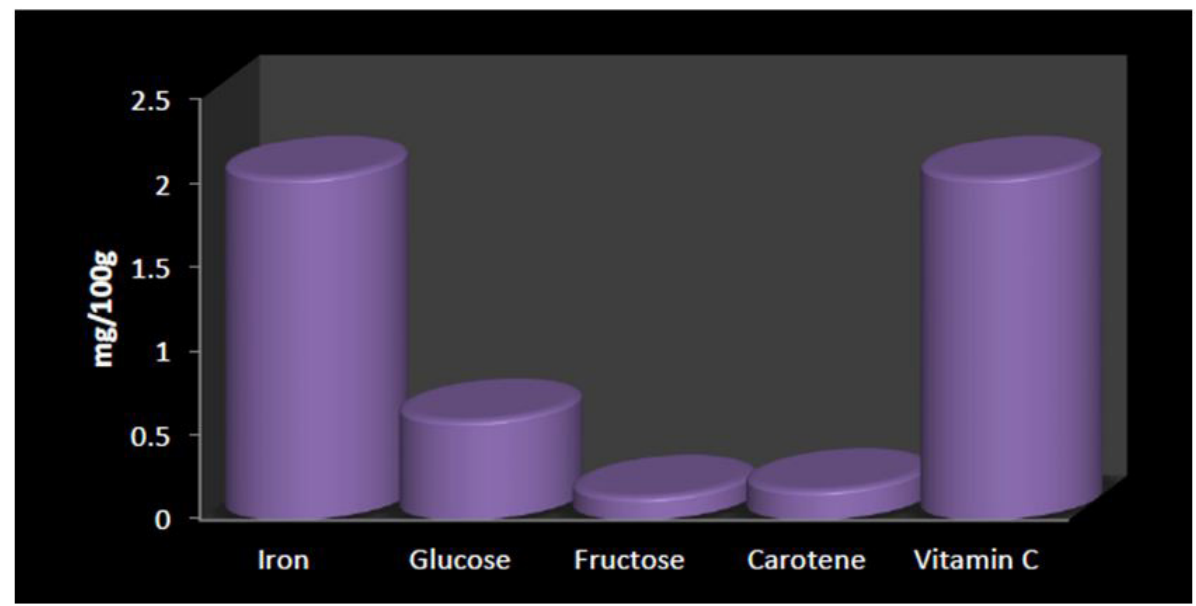

Figure 6: Graphical Representation for Nutritional Quality of IZD 
The Figure 6 above presents the nutritional composition of the IZD developed

\section{Energy (Calorific) Value of the IZD}
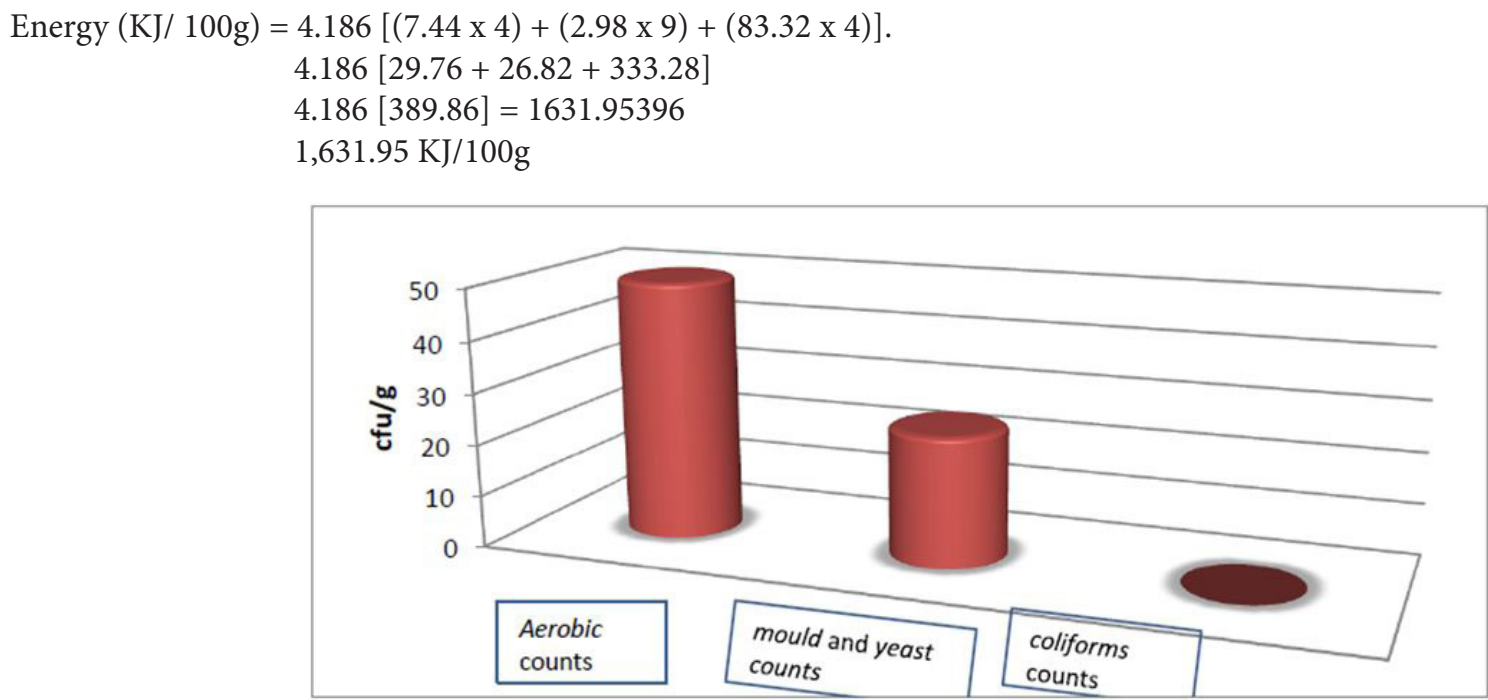

Figure 7: Graphical Representation for Microbiological Quality of IZD

The Figure 7 above presents the microbial composition of the IZD developed.

\section{Results of the Sensory Evaluation}

\begin{tabular}{|c|c|c|c|}
\hline Sensory Attributes & Calculated Values & Tabulated Value & Conclusion \\
\hline Color & -3.21 & 2.262 & $-3.21<2.262$ \\
\hline Flavor & 0.00 & 2.262 & $0<2.262$ \\
\hline Taste (mouth feel) & -1.08 & 2.262 & $-1.08<2.262$ \\
\hline Over all Acceptability & 0.51 & 2.262 & $0.51<2.262$ \\
\hline
\end{tabular}

Table 2 presents the sensory attributes of IZD developed. From the Table 2 above since the calculated values; $-3.21,0.00,-1.08$ and 0.51 are less than the tabulated value; 2.262 ; therefore the colour, flavour, taste and over-all acceptability of both drinks IZD and LZD were not significantly different $(\mathrm{P} \geq 0.05)$ from each other.

\section{Preference Test Analysis}

Twenty five (25) sensory panels of judges who are consumers of Zobo drink were employed in the generation of data by also taste testing samples 531(IZD) and 631 (LZD). The data generated were analyzed using the preference test statistical tool described by Iwe $(2002)$ and Iwe $(2007)[25,26]$. It is noted that the T-tabulated is 2.064 , while T-calculated is -14.37 with standard deviations of 0.32 at $5 \%$ degree of freedom $(\mathrm{P} \geq 0.05)$ between the means; the T-calculated must be greater than the T-tabulated. Hence, there was no significance difference between the IZD (sample 531) and the LZD (sample 631) because T-calculated is not greater than the T-tabulated [24-26].

\section{Microbiological Analysis Results}

The yeast and mould principle was used for the enumeration of yeasts and moulds in the sample, while, the Aerobic Plate Count Method was used for the enumeration of Mesophilic aerobic bacteria in the sample of IZD [23]. The Most Probable Number (MPN) method was used for the enumeration of coliforms. The following microbial results were recorded as presented in Figure 7.

\section{Discussion}

\section{Sensory Evaluation}

Total number of 35 people (panel of judges) that are familiar with LZD was invited to sensorily taste-test both samples of IZD and LZD based on colour, flavour, taste and overall acceptability for t-Test and preference test respectively for 3 consecutive weeks. Thus, familiarity with product category by the panelists need was taken into consideration, coupled with the fact they did not need so much training on sensory method of profiling [27]. Clapperton \& Piggot (1979), Roberts \& Vickers (1994), Walters \& Allshurch (1994), Bende \& Nordin (1997), Hughson \& Boakes (2002) and Labbe et al. (2004) are of the opinion that training and experience increases sensory ability of sensory panel of judges [28-33]. The sensory attributes of IZD and LZD would be significantly different 
if the calculated value obtained is greater than the tabulated $t$-value $(P \geq 0.05)$. Table 2 above shows that the calculated $t$-value for all the sensory parameters indicated no significant difference $(\mathrm{P} \geq 0.05)$ between the LZD and the reconstituted IZD.

There was no significant difference and preference in the sensory attributes of reconstituted IZD produced and the LZD used as reference drink. Hence, the reconstituted IZD can favourable compete with the LZD in the market because the reconstituted IZD was found to be acceptable by the panel of judges. This implies that both samples of reconstituted IZD and the LZD have no significance preference over each other. In other words both samples were accepted equally by the panel of judges.

\section{Proximate Composition}

The moisture content (5.4\%) of the IZD is low which indicates that the IZD has reasonably low moisture content and could have a longer shelf-life if properly packaged as against LZD which deteriorates within 24 hours as a result of fermentation [13]. Hence, one of the major challenges of LZD is spoilage resulting to loss in value of the drink. Although, chemical preservatives such as the Sodium Benzoate and Sodium Meta-bisulphite had been employed in the preservation of LZD, which could only last for few months; but IZD being in powdery form with very low moisture content could possibly last longer than the preserved LZD [17].

The ash content $(0.86 \%)$ of the IZD is low indicating that the drink contains little amount of minerals which are require in the formation of blood cells [34]. Also, Babalola, Babalola and Aworh (2001) reported that Zobo calyces contain mineral elements including potassium, calcium, magnesium, and iron [35]. And reported that potassium is essential for the nervous system, maintenance of muscles, correct rhythm of heart beat, as well as clotting of blood [17].

The protein content (7.44\%) for the IZD is high indicating that it is a good source of plant protein, such as amino acids which are required for growth and development (Orazulike, 2005); also Murano (2003) reports that proteins are essential body builders, because they are composed of sub-units called amino acids that are involved in nearly every biological process in the body [21,36]. The recommended intake of protein is $0.8 \mathrm{~g} / \mathrm{kg}$ of body weight per day for female adults and $0.9 \mathrm{~g} / \mathrm{kg}$ of body weight per day for male adults. The body must always be in a state of positive nitrogen balance, which only dietary protein supplies [21].

That fat content $(2.98 \%)$ of the drink is appreciable indicating that the drink can nourish the consumer with good amounts of fat of plant origin. Fat is a concentrated source of energy which is stored in the body as reserves to be used when energy supply is required by the body Generally, fat helps in the protection of the internal organs such as heart, kidney, lungs and subcutaneous tissues of the skin $[34,36]$.

The carbohydrate content (83.32\%) of the drink is excellently high showing that it is a good source of energy. The high carbohydrates content could be due to the addition of nutritive sweetener, sucrose. The result on carbohydrate content further confirms the results reported by Babalola et al. (2001) [35]. The crude fiber content (1.88\%100g) of the IZD is in appreciable amount showing that the drink contains good amounts of dietary fibre, which increase faecal bulkiness, because their water-retaining properly helps enlarge and soften the stool, and ease its elimination from the stomach [34]. Mostly the larger and softer stool size stimulates the intestinal muscles that promote peristalsis; consequentially, less pressure is needed to expel the stool [34].

From the results of the proximate analysis established, the IZD is good for human consumption. The relevance of proximate analysis in the development of food products needs no emphasis because it is used in monitoring the sensory, nutritional and microbiological quality of food raw materials and products. It is the basis of food products formulation; it remains the only means of maintaining and monitoring the quality standard of foods; and therefore, it is a means of evaluating and monitoring the shelf life of food products [37].

\section{Energy (Calorific) Value}

The calorific value of the instant sorrel drink is $1,631.95 \mathrm{KJ} / 100 \mathrm{~g}$. According to Murano (2003) carbohydrate is the basic fuel for human's metabolic and anabolic activities [21]. The Reference Daily Intake (RDI) of 2000 to 2500 calorie diets has been recommended for an average male and female [21]. The calorific value of a glass of reconstituted IZD is close to the RDI of an average adult.

\section{Nutritional Composition}

The results of the nutritional analysis carried out on sample of sweetened IZD are presented in Table 2. The vitamin C content of sample of IZD is low due to the high temperature the sorrel calyx was subjected to during infusion and dehydration stages of IZD production leading to the destruction of this heat-sensitive vitamin. Increase consumption of vitamin $\mathrm{C}$ might reduce colon cancer development in people, because it has the ability to block the conversion of nitrites and nitrates to potent carcinogens [34]. Also, vitamin C prevents and cures scurvy and plays a role in synthesizing the protein collagen, which is highly concentrated in connective tissue, bone, teeth, tendons and blood vessels [34]. Vitamin C increases the cross-connections between amino acids in collagen, greatly strengthening the tissues it formed; it modestly improves iron absorption; also it is involved in synthesizing certain hormones and neutron-transmitters and it acts as general body antioxidant [34,38]. The adult recommended dietary allowance (RDA) is $60 \mathrm{mg}[34,38]$. The importance of vitamin C cannot be over emphasized; it is usually absorbed by the intestines using a sodium-ion dependent channel, and it will be transported through the intestine via both Glucose-sensitive and Glucoseinsensitive mechanisms [34,38]. 
The iron content of the IZD was $0.60 \mathrm{mg} / 100 \mathrm{~g}$, which forms part of the hemoglobin in red blood cells and myoglobin in muscle cells. Iron participates in the conversion of beta-carotene to Vitamin A hemoglobin molecules in red blood cells transport. Iron is used as part of many enzymes, some proteins and compounds that cells used in energy production. It is also needed for brain and immune function, and contributes to drug detoxification in the liver [34]. The glucose content of the drink was $0.18 \mathrm{mg}$. Glucose is required by the body for energy production, because it is the primary source of energy for human cells. Also, glucose is the main energy source for the red blood cells and central nervous system [34]. The fructose content of the drink was $0.14 \mathrm{mg} / 100 \mathrm{~g}$. Fructose is a monosaccharide (Orazulike, 2005), when it is consumed, it is absorbed by the small intestine and then transported to the liver, where it is quickly metabolized, and much is converted to Glucose, while the rest goes on to form other compounds $[34,36]$. The Glucose is the primary energy fuel which provides the body with instant and constant energy. The calorific value shows without any doubt that the IZD contains Glucose and fructose. However, carbohydrate affects the blood Glucose level which could lead to sharp increase in blood glucose known as glycemic effect $[21,34]$.

Therefore, persons who have disorders of Glucose metabolism, such as diabetes and hypoglycemia should consume foods associated with low glycemic effect, owing to the fact that the metabolism of these individuals cannot easily cope with the rapid increase in blood Glucose caused by high glycemic foods [21]. However, the presence of large quantities of sugar in the blood can slow absorption of nutrients [38].

The carotene content $(0.18 \mathrm{mg} / 100 \mathrm{~g})$ of the IZD is low, which is termed as vitamin A pre-cursor (i.e. Pro-vitamin A); the preformed Vitamin A and the Pro-vitamin A (i.e. Carotenoids) both make up what is generally referred to as the Vitamin A, which performs functions such as promotion of vision, promotion of growth, prevention of the drying of skin and eye, and as well it promotes resistance of bacterial infection [34].

The nutritional quality of the IZD was found to be moderate and appreciable. The relevance of nutritional evaluation in food product development needs no emphases, because foods and drinks are formulated according to the nutritional requirement of the target consumers [37].

\section{Microbiological Quality}

Figure VII illustrates that the IZD developed had count of 50 bacterial cells per gram. However, the colony forming units per gram (cfu/g) of the IZD was less than 10 , but the yeast, moulds count was $25 \mathrm{cfu} / \mathrm{g}$, and coliform cells counts recorded less than 10 count. The coliform tests carried out on the drink showed no presence of coliform bacteria cells, because the experimental tubes remained unchanged, without gas development in the Durham tubes throughout the experimental period. The tubes showed no metallic sheen development in the Durham tubes, which confirms the absence of coliform cells in the analyzed IZD. This indicates a high microbial quality of the sample of the IZD. In a nut shell, from the microbiological quality assessment results obtained in this study, the IZD recorded 50 colony forming units per gram of bacterial cell counts indicating a low bacterial cell counts in the IZD; and it has been established by the HPA (2004) that high bacterial cell count of 100 and above is an indicator of the overall degree of microbial contamination of foods [23]. Mohammed and Ismail (2014) reported that zobo drink harbours bacteria such as the Bacillus species [4].

Also, the IZD contained $25 \mathrm{cfu} / \mathrm{g}$ of yeasts and moulds spores; and the coliform recorded less than $10 \mathrm{cfu} / \mathrm{g}$ counts of cells. When Coliform cells recorded is less than 10 counts of cells; this may possibly infers that the drink is fit for human consumption, because according to HPA (2004) E. coli counts of 100 colonies forming units per gram or greater are considered to be unsatisfactory for ready to-eat food [23]. Commercial guidelines for ready-to-eat food generally set the target at value at 10cfu. Also, the counts recorded in the developed IZD is less than the standard set by the International Commission on Microbiological Specification of Food that set a limit of $10^{6} \mathrm{cfu} / \mathrm{g}$ for aerobic count of foods; and coliform count of less than $10^{2} \mathrm{cfu} / \mathrm{g}$ [39]. As for the IZD developed less than $10^{1} \mathrm{cfu} / \mathrm{g}$ of cells of coliform was recorded indicating this drink contains few cells of coliform. This study suggests that the developed IZD was produced under hygienic conditions and it was regarded safe for human consumption.

\section{Conclusion}

The use of purple sorrel calyx in the production of IZD was achieved using the infusion, dehydration and size reduction method. This product in a powdery form was found to contain appreciable nutrients; it was accepted by the sensory panelists and microbiologically safe for human consumption within the period of this study. The product is likely to be shelf-stable compared to the LZD because of high content of moisture that usually has a shelf-life of less than 24 hours at an ambient temperature of between $35^{\circ} \mathrm{C}$ and $37^{\circ} \mathrm{C}$. Therefore this study suggests that this method of production is recommendable for the production of safe IZD. This is because most consumers perceived LZD as un-hygienic, especially the elites and the working class. Therefore, the IZD would be more acceptable and patronised by the growing population of ZD consumers.

\section{Recommendations for further study}

The following further works should be conducted on the IZD:

a. Shelf-life study.

b. Micro-nutrients content. 
c. Solubility/dissolve-ability test.

d. Other methods of production, such as extraction, concentration and dehydration method should be employed in the production of IZD. However, freeze dryer or spray dryer would be required in the dehydration of the concentrated LZD so that micronutrients that are heat-sensitive such as Vitamin C could be saved from destruction due to high temperature.

\section{References}

1. Alobo AP, Adeleiye PO, Abugh M, Atser AJ (2009) Consumer Use and Attitude Towards Zobo: A Nigerian Sorrel Drink. Nigerian Food Journal 27: 219-28.

2. Muhammad FS, Umar BM (2007) Production and Organoleptic Assessment of Sweetened Sorrel Powder. Namoda Tech-ScopeJ Appl Sci Technol 7: 7-13.

3. Hassan MK, Beman-Ali, JK Mohammad AA, Farhad F (2009) Effects of Sour Tea (Hibiscus sabdariffa) on Lipid Profile and Lipoproteins in Patients with Type II Diabetes. J Altern Complement Med 15: 899-903.

4. Mohammed FS, Ismail BB (2014) Comparison on Two Methods of Preparation of Zobo Drink on the Survival of Bacillus spp. Am J Food Technol 9: 200-8.

5. Morton JF (1999) Roselle, Hibiscus sabdariffa L. Retrieved on 26th July, 2005.

6. Olayemi F, Adebayo R, Muhammad R, Bamishaye E (2011) The Nutritional Quality of Three Varieties of Zobo (Hibiscus sabdariffa) Subjected to the same Preparation Condition. Am JFood Technol 6: 705-708.

7. Babalola SO (2000) Chemical Analysis of Roselle Leaf (Hibiscus sabdariffa), in Proceeding of 24th Annual Conference of Nigerian Institute of Food Science \& Technology 228-9.

8. Schippers RR (2000) African Indigenous Vegetable: An over view of the Cultivated Species. Chatham, UK; Natural Resources Institute/ACP-ED Technical Centre for Agricultural and Rural Cooperation.1-214.

9. Mazza G, Miniati E (1993) Anthocynins in Fruits, Vegetables and Grains. Bocaraton, Florida: CRC Press

10. Bridle P, Timberlake CF (1997) Anthocynins as Natural Food Colours: Selected Aspects. Food Chem 58: 103-9.

11. Pesen Özdoğan F, Orhan N, Ergun F (2011) Studies on the Conformity of Hibiscus sabdariffa L. Samples from Turkish Market to European Pharmacopeia. FABAD J Pharm Sci 36: 25-32

12. Oboh G, Elusiyan CA (2004) Nutrient Composition and Anti-microbial Activity of Sorrel Drinks (soborodo). J Med Food $7: 340-2$.

13. Mohammed SF (2005) Effects of Growing Conditions of the Quality of Sorrel Calyces (Hibiscus sabdariffa) and Sorrel Drinks. Dep Food Sci Technol,Kaduna Polytechnic, Kaduna.

14. Ukwuru MU, Uzodinma CC (2010) Preservative Effect of Spices and their Flavour Acceptability in Zobo Drink. Niger Food J 28: 265-274.

15. Nwachukwu E, Onovo OM, Eadie T (2007) Effect of Lime Juice on the Bacterial Quality of Zobo Drinks Locally Produced in Nigeria. Res J Microbiol 787-891. 16. Ayo JA, Tehinse JF (2006) Food Dehydration: Principles and Practice, $1^{\text {st }}$ Ed. Kaduna: Amana Printing and Advertising Ltd. Pp. 171-202.

17. Mohammed SF (2010) Production and Evaluation of Instant zobo drink (Hibiscus sabdariffa). Depart Food Sci Technol College of Food Technology, Federal University of Agriculture, Makurdi, Benue state.

18. AOAC (2000) Official Method of Analysis of Association of Analytical Chemists, AOAC International, (17 ${ }^{\text {th }}$ Ed.). Washington D.C 274-310.

19. Pearson D (1976) Chemical Analysis of Foods, $7^{\text {th }}$ Ed. Churchill Livingstone, Edinburgh, London and New York.

20. Onwuka GI (2005) Food Analysis and Instrumentation: Theory \& Practice, $1^{\text {st }}$ Ed. Lagos: Division of HG Support Nigeria Ltd 80,113-114,126.

21. Murano PS (2003) Understanding Food Science and Technology. USA: Thomas Learn Acade Resou Cent.63-75,82-83.

22. Magdi AO (2004) Chemical and Nutrient Analysis of Baobab (Andansonia digiata) Fruit and Seed Protein Solubility. Plant Foods Hum Nutr 59: 29-33.

23. Health Protection Agency (2004) Aerobic Plate Count at 30oC: Surface Plate Method. National Standard Method F10 Issues 1.

24. Ihekoronye AI, Ngoddy PO (1985) Integrated Food Science and Technology for the Tropics. London.173-193.

25. Iwe MO (2007) Current Trends in Sensory Evaluation of Foods, $1^{\text {st }}$ Ed. Enugu, Nigeria: RojointCommunication Services Ltd 136-139.

26. Iwe MO (2002) Handbook of Sensory Methods \& Analysis. Enugu, Nigeria: Rojoint Communication Services Ltd 71-78.

27. Bitnes J, Rodbotten M, Lea P, Ueland Q, Martens M (2007) Effect of Product Knowledge on Profiling Performance Comparing Various Sensory Laboratories. J Sens Stu 22: 66-80.

28. Clapperton J, Piggot J (1979) Flavour Characterization by Trained and Untrained Assessors. J Inst Brewi Distil 85: 275-7.

29. Roberts A, Vickers ZM (1994) A Comparison of Trained and Untrained Judges Evaluation of Sensory Attributes Insensitivities and Liking of Cheedar Cheeses. J Sen stu 9: 1-20.

30. Walters CJ, Allchurch EM (1994) Effect of Training Procedure on the Performance of Descriptive Panels. Food Qual Pref 5: 203-14.

31. Bende M, Nordin S (1997) Perceptual Learning in Olfaction: Professional Wine Tasters versus Controls. Physiol Behav62: 1065-70.

32. Hughson AL, Boakes RA (2002) The Knowing Nose: The Role of Knowledge in Wine Expertise. Food QualPref 13: 463-472.

33. Labbe D, Rytz A, Hugi A (2004) Training is a Critical Step to Obtain Reliable Product Profiles in a Real Food Industry Context. Food QuaL Pref 15: 341-348.

34. WardlawGM (2001) Contemporary Nutrition: Issues and Insights, 4th Ed.Boston: GrawHill Higher Education 104-5, 145-8, 211-4, 240-2, 281-7.

35. Babalola SO, Babalola AO, Aworh OC (2001) Compositional attributes of the calyces of roselle (Hibiscus sabdariffa L). J Food Technol Africa.

36. Orazulike RE (2005) Human Nutrition in the Tropics -A Case Focused Approach. Bauchi: ALPHA Graphics Publications 10-60.

37. Onuorah CE, Ayo JA, Uhiara NS, Jideani VA (2004) Food Product Development, 1st Ed. Kaduna: Amana Printing and Advertising Ltd. 117-118 and 135.

38. Wilson JX (2005) Regulation of Vitamin C Transport. Annu Rev Nutr 25, 105-25.

39. ICMSF (2002) International Commission on Microbiological Specifications for Foods Microorganisms in Foods 7 (2002) Microbiological Testing in Food Safety \& Management. New York, USA Academ Publi 70-80. 


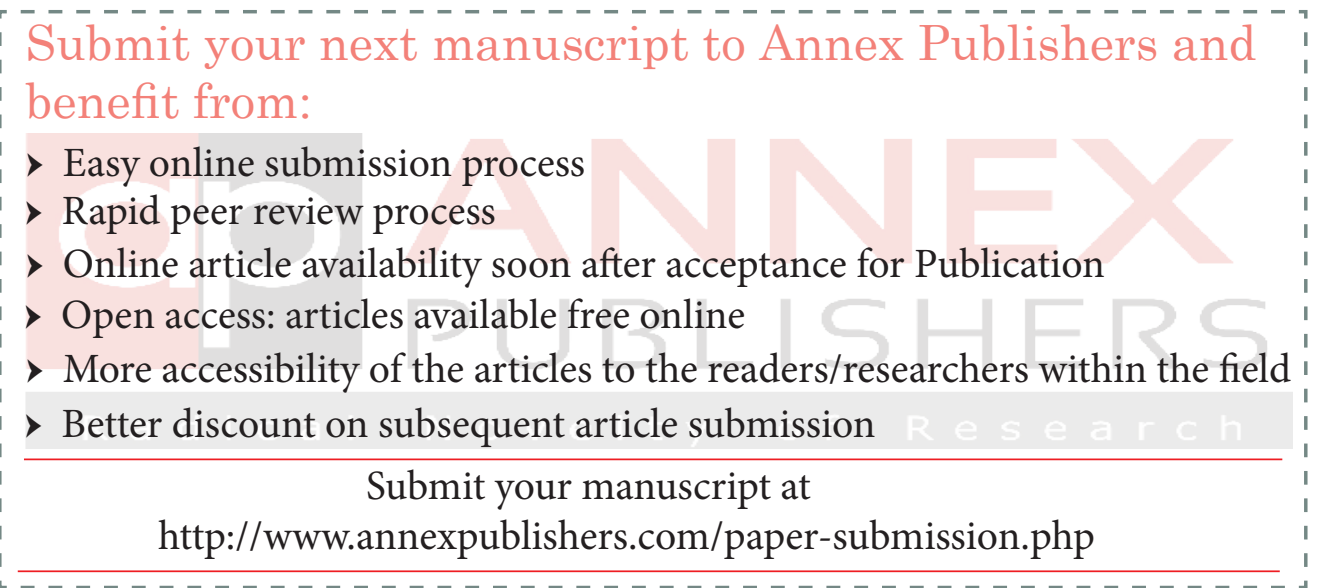

